\title{
Movimento trans em Belo Horizonte: resgatando o histórico e mapeando o presente*
}

Thiago Coacci **

\section{Resumo}

Este estudo objetiva contribuir para a reflexão sobre o movimento de pessoas trans no Brasil, com um foco específico na cidade de Belo Horizonte. Apesar da grande produção sobre pessoas trans na academia, pouco se produziu sobre o movimento de pessoas trans, e menos ainda sobre o contexto local de Belo Horizonte, onde, caso não seja registrada, corre-se o risco de perder a história do movimento que, costumeiramente, é repassada de forma oral pelas travestis e transexuais mais velhas. Busca-se, então, resgatar a história do movimento em Belo Horizonte e mapear o presente, identificando quais são as principais: a) organizações e grupos do movimento trans em atividade atualmente; b) demandas do movimento; c) estratégias e táticas de ação utilizadas por tais organizações e grupos; e por último, d) parcerias $e$ alianças realizadas. Este trabalho foi realizado por meio de entrevistas com cinco ativistas do movimento de Belo Horizonte.

Palavras-chave: Movimentos Sociais, Pessoas Trans, Belo Horizonte.

* Recebido em 14 de janeiro de 2017, aceito em 22 de maio de 2018.

** Professor substituto no Departamento de Ciência Política da Universidade Federal de Minas Gerais (UFMG), Belo Horizonte, MG, Brasil. thiagocoacci@gmail.com / http://orcid.org/0000-0001-6493-0977 
Transgender Movement in Belo Horizonte: Preserving the Past and Mapping the Present

\begin{abstract}
The objective of this paper is to contribute to the study of the transgender movement in Brazil, focusing on the city of Belo Horizonte. Despite considerable academic production about trans people in Brazil, there are few studies on the transgender movement in the country, and even fewer about the local context of Belo Horizonte. If it is not recorded, there is a risk of losing the history of the movement in this city, which is routinely passed on orally by older travestis and transgender women. Therefore, this study aims to recover the history of the movement in the city and map the present, identifying the main: a) organizations and groups in the transgender movement that are currently active; b) demands of the movement; c) strategies and tactics of action used by these organizations; and d) the partnerships and alliances they form. The study was conducted through interviews with five activists from the movement in Belo Horizonte.
\end{abstract}

Keywords: Social Movements, Transgender People, Belo Horizonte. 


\section{Introdução}

Eram sete e cinco, início de uma noite chuvosa, do dia 02 de dezembro de 2015. Havia combinado de encontrar com Anyky Lima às sete, para entrevistá-la. Já estava cinco minutos atrasado e provavelmente atrasaria vários outros. Saí de casa com tempo de sobra para chegar à casa de Anyky, pois sabia que ela é sempre pontual e preza por isso. No entanto, o trânsito estava muito pesado, ainda pior que o normal, devido à forte chuva que naquele momento já raleava. Anyky mora no Carlos Prates, algumas ruas acima da avenida Pedro II. Quem conhece Belo Horizonte sabe duas coisas sobre essa avenida: primeiro, que o trânsito ali é péssimo na "hora do rush", justamente o momento que eu precisava passar por lá; e, segundo, que à noite a avenida se transforma em um ponto de prostituição de travestis e mulheres trans.

Passados cinco minutos, durante os quais eu não havia avançado nem um metro sequer, peguei o telefone e mandei a seguinte mensagem pelo mensageiro do facebook: "Anyky eu tô aqui do lado, mas o trânsito tá péssimo na Pedro II. Desculpa o atraso! Já já tô aî". Para comprovar que eu não estava mentindo e evitar um mal-estar antes da entrevista, enviei também a minha localização no GPS. Anyky rapidamente respondeu "Eu imagino". A chuva já estava bem fraca e dando sinais de que, em pouco tempo, pararia por completo. Enquanto o trânsito não andava, fiquei observando as primeiras travestis que, corajosamente, já estavam nos passeios e esquinas exibindo seus corpos para os potenciais clientes nos carros.

Essa cena é bastante comum em Belo Horizonte e em diversas outras cidades do Brasil. É difícil ir a uma grande cidade brasileira que não tenha um ponto de prostituição de travestis $e$ mulheres trans. Para além das ruas, pessoas transexuais e travestis já possuem uma visibilidade grande no Brasil e isso não é de hoje. Quem alardeia a "novidade" de travestis e transexuais parece se esquecer de que, já nas décadas de 1960 e 1970, Rogéria tornavase conhecida por fazer sucesso em peças de teatro e filmes no 
cinema; que, na década de 1980, modelos como Thelma Lipp e Roberta Close roubavam a atenção de todo o Brasil por sua beleza. Roberta ${ }^{1}$ chegou a aparecer na capa da revista Playboy, em 1984, e Thelma também virou capa de diversas revistas, numa espécie de disputa entre as duas, criada pela mídia. De fato, nos últimos anos, essa visibilidade tem se tornando maior e pessoas trans, cada vez mais, ocupam espaço na mídia, fora dos famigerados noticiários policiais que anunciam, quase sempre de forma preconceituosa, suas mortes bárbaras ou escândalos sensacionalistas envolvendo seus relacionamentos com jogadores de futebol e políticos. Apesar dessa crescente visibilidade, a violência contra pessoas trans, no Brasil, ainda hoje, tem números gravíssimos.

$\mathrm{Na}$ academia, a visibilidade das pessoas trans também é ascendente. A busca no portal Scielo pelos termos "travesti" ou "transexual" retorna 129 textos - a primeira publicação data de 1999 e há uma curva ascendente, a partir do ano de 2008. Os textos, segundo a classificação do Scielo, derivam de diversos campos do saber, como a saúde pública, psicologia, sociologia, antropologia, linguística, história, economia, medicina e áreas multidisciplinares. Se a mesma busca for realizada em outros bancos de dados, como o Google Scholar, o número de resultados será, com certeza, infinitamente maior.

Se é verdade que os estudos sobre travestilidade $e$ transexualidade estão em um crescimento vertiginoso, alguns temas ainda são pouco abordados. Especificamente sobre como essas pessoas se organizam politicamente, isto é, sobre o Movimento de Pessoas Trans, pouco se tem estudado. Tal história encontra-se, em grande parte, espalhada de forma não sistemática por alguns trabalhos que abordam o movimento, sem tê-lo como preocupação central, como é o caso dos trabalhos de Teixeira (2013), Peres (2015), Bento (2006), Ávila (2015), Facchini (2003), Simões; Facchini (2009) e diversos outros. O estudo específico sobre o movimento de pessoas trans foi realizado, de forma

1 Busca realizada em 20 de fevereiro de 2019. 
pioneira, nos trabalhos de Mário Carvalho (2011, 2015; Carvalho; Carrara, 2013), que focaram mais fortemente no movimento nacional e nas articulações nas cidades de São Paulo e Rio de Janeiro. Não há nenhum estudo específico sobre o movimento de pessoas trans em Belo Horizonte, apenas um pedaço da história se encontra contado por Machado (2007) que, ao estudar o Movimento LGBT de Belo Horizonte, analisou brevemente a história de uma organização fundada na década de 1990 por travestis e mulheres transexuais.

Este estudo é uma tentativa de contribuir para a reflexão sobre o movimento de pessoas trans no Brasil, mas com um foco específico para a cidade de Belo Horizonte. Por tratar de uma lacuna na literatura, tem um caráter exploratório e descritivo, sem a pretensão de testar hipóteses ou produzir generalizações. Buscase, então, identificar quais são as principais: a) organizações $e$ grupos do movimento trans em atividade; b) demandas do movimento; c) estratégias e táticas de ação utilizadas por tais organizações e grupos; e, por último, d) parcerias e alianças realizadas.

\section{Entrando em campo}

Uma vez definido os objetivos do estudo, restava saber como colocá-lo na prática. A entrada em campo para o tipo de pesquisa que me propus não é nada banal, e vinha acompanhada de uma série de dilemas metodológicos e teóricos. Primeiramente, me inquietava como realizar o estudo: quais seriam as melhores técnicas de coleta de dados para responder as perguntas que me interessavam? Ficava na minha cabeça, ainda, uma segunda questão, que é teórica, mas com efeitos bastante práticos, de como recortar o campo definindo: o que é e o que não é o movimento trans? Isso é, se é que existia algo para ser nomeado como movimento trans em Belo Horizonte... Acreditava que essas dúvidas estavam intimamente relacionadas $e$ para responder a primeira, era preciso responder a segunda também. 
O campo de estudos sobre movimentos sociais é aberto a uma pluralidade de metodologias $e$, mais do que isso, tem incentivado a mistura de técnicas diferentes. Della Porta (2014a, 2014b) aponta uma série de razões que levariam a esse pluralismo metodológico, como o pluralismo teórico interno ao campo de estudos de movimentos sociais e o fato de que os movimentos sociais, em geral, não produzem um registro sistemático de suas ações, sendo que, muitas vezes, não possuem, sequer, uma lista de integrantes. Esses registros são produzidos, geralmente, por movimentos altamente institucionalizados e profissionalizados, como é o caso do Greenpeace ou outras organizações similares. Em meus contatos preliminares, não me parecia que esse era o caso do movimento de pessoas trans. Além disso, a falta de estudos prévios sobre o campo em Belo Horizonte aumentava as incertezas. Se o campo já fosse mapeado, seria mais fácil identificar organizações e pessoas-chave para conseguir as informações necessárias ou, até mesmo, seria possível utilizar os dados levantados previamente para realizar uma nova análise sobre eles.

Devido à minha militância no movimento LGBT em Belo Horizonte, eu sabia que, em determinado momento da história da cidade, existiu uma organização exclusiva de travestis $e$ transexuais, a ASSTRAV, mas não tinha certeza se essa se encontrava ou não em atividade. A busca na internet dava sinais de inatividade, visto que o blog da associação se encontrava sem novas postagens desde 2004. Via, também na militância, uma série de pessoas organizando ações em prol dos direitos das pessoas trans, convocando jogos em praças públicas, frequentando reuniões em espaços de decisão, organizando palestras, fazendo campanhas virtuais etc. Será que isso poderia ser considerado um movimento trans? Afinal, o que é um movimento social e para onde eu deveria olhar em minha pesquisa?

Os estudos de movimentos sociais fazem parte de um campo já consolidado nas ciências sociais e que conta com contribuições de muitas outras áreas do saber, como a psicologia, 
a filosofia e a educação. Tradicionalmente, os analistas dividem as abordagens entre americanas e europeias, dentre essas dividem, ainda, em diversas correntes, cada qual com suas particularidades. Essa pluralidade de abordagens torna difícil atingir alguns consensos em questões básicas, como o que seria considerado um movimento social.

Um dos conceitos clássicos, de autoria de Charles Tilly (Tilly; Wood, 2013), afirma que um movimento social é composto por um conjunto de três elementos: campanha, repertório $e$ demonstrações de VUNC (Valor, Unidade, Número $e$ Comprometimento). Esse conceito me parece dar demasiada ênfase numa sequência de ações coletivas, mais ou menos estáveis no tempo e coordenadas por uma organização ou liderança. Além disso, faz exigências que são difíceis de serem cumpridas por uma população altamente marginalizada, como as pessoas trans. Como exibir valor, quando a sociedade não valoriza os seus atributos e sua cultura? Como exibir números $e$ comprometimento, quando se trata de uma população que tem medo da polícia e de se mostrar de dia, que desconfia do Estado e que em função da exclusão do mundo do trabalho acaba, muitas vezes, por trabalhar à noite no mundo da prostituição? Será que, em Belo Horizonte, não existiria um movimento trans? Ou então, será que a minha percepção estaria errada?

Por uma influência cruzada de Alberto Melucci (1996) e Sônia Alvarez (2014), trabalho com a ideia de que movimento social é um termo analítico para recortar da realidade um campo discursivo de ação. Segundo Alvarez, essa noção, mais ampla que a de Tilly, permite perceber que os movimentos sociais se expandem horizontalmente, para além da sociedade civil, em direção a outras formas organizacionais e, também, verticalmente em direção ao Estado. Tal concepção permitiria escapar de alguns dilemas clássicos das teorias dos movimentos sociais, são eles:

(i) estado vs. movimentos sociais, principalmente no contexto da emergência da esquerda e das reformas do Estado na América Latina, que promoveu uma série de políticas de 
participação e deliberação, bem como com a entrada de ativistas históricos para cargos políticos variados, o que tornou tal fronteira porosa e instável. A noção de campo permite, então, localizar as múltiplas formas de relação $e$ interpenetração de coletivos, ativistas autônomos, partidos políticos, agentes públicos e o Estado, em uma disputa política;

(ii) coletivo vs. indivíduo, dado o contexto em que as formas de mobilização e participação se multiplicaram, dentro do sistema político formal (criação de conselhos, conferências, orçamentos participativos), e fora desse (no facebook, na academia, artivismos $e$ hacktivismo), o que permitiu que ativistas autônomos da internet possam, inclusive, atuar como lideranças e pautar determinados debates e disputas, se reivindicando como parte de um movimento, mesmo sem possuir filiação a organização ou partido, perde o sentido analítico focar exclusivamente em campanhas sistemáticas protagonizadas por organizações.

Essa concepção se adequa mais à realidade que eu preliminarmente vislumbrava. Com essa noção de movimento enquanto campo discursivo, perdia o sentido a pergunta se aquilo que eu observava podia ou não ser chamado de movimento social, uma vez que esse não é um objeto empírico, mas uma construção analítica.

Sendo assim, devido a (i) concepção de movimento social como "campo", (ii) falta de dados preliminares sobre o movimento, (iii) impressão de um campo fluido, com uma institucionalização precária e (iv) pela ausência de registros sistematizados da atuação das organizações e lideranças, avaliei que a melhor forma de "entrar em campo" para a pesquisa exploratória seria por meio de entrevistas semiestruturadas com pessoas-chave do movimento. Semiestruturadas porque, apesar de possuírem uma estrutura prévia de perguntas que buscavam responder aos objetivos do trabalho, me dariam flexibilidade suficiente para explorar tópicos que eu poderia desconhecer no início da pesquisa. 
Dois outros fatores influenciaram a minha opção pelas entrevistas. Primeiramente, como argumenta Brown (2015), as fontes tradicionais como jornais, revistas, documentos oficiais $e$ jurídicos tendem a sub-representar as histórias das pessoas trans ou, então, representá-las de uma forma distorcida ou negativa, como pessoas criminosas, doentes e/ou exóticas, sendo, então, preferível escutar as narrativas da experiência das próprias pessoas. Para um grupo de pessoas para que o anonimato é o padrão, dar visibilidade a essas vidas se torna algo relevante. Em segundo lugar, na minha percepção, os movimentos sociais de Belo Horizonte seriam altamente personalizados. Como perceberemos, mesmo quando existia uma organização institucionalizada, a história da organização se confundia $e$ misturava com a história de um pequeno número de pessoas. A pesquisa de Machado (2007) corrobora essa percepção, mostrando, inclusive, a existência de uma crítica jocosa a certas organizações do movimento LGBT que, por serem centralizadas na figura de uma única pessoa, são chamadas pejorativamente de ING, isto é, Indivíduos Não Governamentais.

Iniciei entrevistando duas pessoas que já conhecia e que, a partir de meus contatos nos espaços conjuntos de militância e pela percepção de uma visibilidade nas redes sociais da internet, julguei serem de destaque no movimento local. Entrevistei, assim, o Carl Benzaquen, homem trans, que na época era integrante do MOOCA e a Anyky Lima, travesti, que ocupava o cargo de presidenta do CELLOS-MG ${ }^{2}$ e representante da ANTRA em Minas Gerais. Escolhi propositalmente uma pessoa de identidade de gênero feminina e outra masculina, por entender que essas identidades possuem suas especificidades e algumas demandas diferentes. A partir das entrevistas iniciais, a pesquisa seguiria pela técnica da bola de neve, entrevistando pessoas que fossem indicadas como relevantes pelas anteriormente entrevistadas. Entrevistei, em seguida, Gisella Lima e Bruno Souza, e por fim, Walkíria La Roche. Tentei, ainda, entrevistar uma série de

${ }^{2}$ Centro de Luta pela Livre Orientação Sexual. 
pessoas, mas fui frustrado em minhas tentativas com elas: Vanusa, Luisa Ferreira (Pfeiffer), Raul Capistrano e Liliane Anderson. Raul e Liliane até aceitaram meu convite, respondendo simpaticamente à tentativa de entrevista, mas nossas agendas não bateram $e$ as entrevistas não puderam ser realizadas.

\section{Anyky e Walkíria, a ASSTRAV e CELLOS}

"Mas pera aí, é movimento LGBT ou Trans? O T de LGBT não significa trans, são coisas diferentes?"

Desde que comecei a estudar o movimento trans brasileiro, para escrever meu projeto inicial de doutorado, escutei essa pergunta diversas vezes. A verdade é que a resposta a essa pergunta não é nada simples.

Tanto o movimento LGBT quanto o movimento de pessoas trans são movimentos identitários, mas as identidades que são a base para tais movimentos não são fixas e estáveis. Tais identidades e os termos que as nomeiam foram sendo construídas, paulatinamente, ao longo do último século (Bento, 2006; Foucault, 2009; Fry, 1982; Green, 2000; Leite Jr., 2011) e isso teve reflexo nas mudanças de nome e nas reconfigurações que os movimentos passaram desde sua formação. Como ensinam Facchini e Simões (2009), o movimento já se intitulou "movimento homossexual" na década de 1970, a partir dos anos 1980 e início dos anos 1990 foi, pouco a pouco, tomando um foco identitário, alternando entre movimento gay e lésbico, movimento de gays, lésbicas e travestis, movimento GLBT e finalmente, em 2008, a atual "sopa de letrinhas", LGBT.

Especificamente o que chamo, hoje, de "pessoas trans", como uma categoria política abrangente que engloba travestis, transexuais, homens trans e uma série de outras identidades, é uma construção bastante recente. Ao entrevistar Anyky, que completou há pouco 60 anos, comecei por perguntar como ela se identificava. Anyky foi direta ao me dizer que se identificava como travesti. Não sabia me dizer, ao certo, quando começou a se 
identificar assim, mas foi expulsa de casa na década de 1960, quando tinha 12 anos, e já naquela época se identificava assim.

Anyky: Então eu sempre fui travesti. Não existia outro nome além de travesti. Pelo menos que eu soubesse, não existia outro nome. Só existia travesti. [...] E eu sempre ouvi falar na palavra travesti, eu nunca tinha ouvido falar em transexual. Ou era travesti, lésbica e gay. Só isso, não tinha outra definição. Hoje em dia é que tem muitas definições, tem muita coisa, né?

Carvalho e Carrara (2013) afirmam que o termo travesti nem sempre foi utilizado como uma categoria identitária; até a década de 1950, o termo era utilizado majoritariamente em frases como "estar em travesti", dando um sentido de um estado temporário, uma caracterização, podendo ser utilizado, inclusive, para referirse a homossexuais afeminados e que ocupavam a posição passiva na relação sexual (sendo penetrado). O modelo "da bixa e do bofe" (Fry, 1982) que imperava na época misturava gênero $e$ sexualidade de forma quase inseparável. Seria a partir da década de 1960, com a progressiva degradação desse modelo, que travesti foi se consolidando como uma categoria identitária. Outros termos, como transexual e transgêneros, diferenciando categorias além da travesti, surgem apenas mais recentemente no debate público, datando do final dos anos 1990 e início dos anos 2000 (Carvalho; Carrara, 2013).

As histórias dos movimentos e das ativistas também se misturam. Das cinco pessoas entrevistadas, apenas Bruno, talvez por ser mais novo e mais recente na militância, não teve passagem por organizações mistas LGBT. O movimento LGBT brasileiro teria nascido, ao menos em sua forma minimamente institucionalizada, no final da década de 1970 (Simões; Facchini, 2009), e desde essa época já contava com a participação de pessoas que, hoje, seriam consideradas pessoas trans (Carvalho, 2011). As primeiras organizações do movimento trans, por sua vez, teriam surgido na década de 1990, impulsionadas por dois fatores: a violência 
policial e a epidemia de HIV/AIDS (Carvalho; Carrara, 2013). Em Belo Horizonte, a história parece ser similar.

Walkíria La Roche é uma das precursoras do movimento trans em Belo Horizonte. Walkíria diz que se identifica como mulher desde que se entende por gente, e que se a sociedade $e$ a medicina chamam isso de uma mulher transexual ou travesti, pouco importa. Ela não liga para essas "caixinhas", mas reconhece a importância política dessas identidades. Sua luta começou pela própria sobrevivência, pois foi discriminada dentro da própria casa $e$ isso a ensinou a reagir, a não aceitar a discriminação da polícia, das boates e outros espaços.

\begin{abstract}
Walkíria: Acho que é uma ação e reação mesmo, né? Você me agrediu, eu também sabia me defender, de uma forma até um pouco mais agressiva, porque é uma outra época. Quando a gente narra essas questões ou discorre sobre essas questões, a gente vê que hoje é um contexto completamente diferente, as pessoas não conseguem remeter isso a um passado. $\mathrm{Na}$ minha geração existia tipificação do código de vadiagem, então se você estava após as dez horas da noite na rua, você era presa por vadiagem. As pessoas poderiam te pegar simplesmente por você estar andando na rua, você não estava fazendo nada você estava andando na rua. Então eu percebi essa militância, se eu puder falar isso, desde nova. $\mathrm{Na}$ adolescência, eu já estava ali em grupos, não aceitando não entrar nos lugares.
\end{abstract}

A crise da AIDS foi outro estopim para a atuação política de Walkíria. Na década de 1990, Walkíria já trabalhava em algumas boates de Belo Horizonte, como recepcionista e fazendo alguns shows. Nessas oportunidades, ainda de forma individual, aproveitava para falar sobre o perigo da AIDS: "Não existiam os coquetéis, então as pessoas realmente tinham a AIDS como uma questão de morte mesmo". Falava, então, da importância de se prevenir, de usar camisinha. Certo dia, Porcina D'Alessandro assistiu a um show e ao final convidou Walkíria para participar das 
reuniões do $\mathrm{GAPA}^{3}$, local onde também conheceu outra das entrevistadas, Anyky Lima.

Anyky não é natural de Belo Horizonte, mas no início dos anos 1990 se mudou para cá. Com pouco tempo na cidade, Anyky, que naquele tempo se prostituía, conheceu Roberto Chateaubriand e, por seu intermédio, logo começou a participar de um projeto de prevenção de DST/AIDS do grupo GAPA, presidido por Roberto. Anyky trabalhava nesse projeto junto a diversas outras travestis e transexuais como Porcina, Zoraide $e$ Vanusa. Foi no espaço do GAPA que surgiram as primeiras conversas sobre montar uma ONG especificamente trans em Belo Horizonte, projeto que foi concretizado alguns anos mais tarde com a fundação da ASSTRAV. Como conta Anyky:

o papo da ASSTRAV surgiu justamente ali. Sabe, nessas reuniões da gente, nesses bate-papos. E a Porcina começou a falar que ela tinha vontade de fundar uma ONG, e num sei mais o quê. Aí, o papo surgiu daí.

A década de 1980 marca uma reconfiguração do movimento homossexual. Em função da epidemia do HIV/AIDS e do estigma associado a essa doença, diversos grupos da década de 1970 deixaram de existir ou mudaram seu foco para trabalhar com prevenção (Facchini, 2003). O GAPA é um dos grupos que surgiram, no final da década de 1980, para trabalhar com a questão. Em Belo Horizonte, a ONG foi fundada em 1987 e não se propunha como uma organização do movimento LGBT, mas devido a uma série de fatores, como a orientação sexual dos fundadores $e$ os projetos de prevenção voltado aos homens que fazem sexo com homens (HSM) e às travestis, o grupo acabou por "protagonizar uma nova fase do movimento gay em Belo Horizonte" e a funcionar quase que como "uma incubadora [...] da questão das travestis" (Machado, 2007:96-99).

A ASSTRAV foi fundada no final da década de $1990^{4}$ por Porcina D'Alessandro e Walkíria La Roche, e foi a primeira

${ }^{3}$ Grupo de Apoio e Prevenção à Aids. 
organização exclusiva de pessoas trans em Belo Horizonte. Institucionalmente, a organização seguia o modelo do GAPA, pois, nas palavras de Walkíria: "a gente não tinha outra referência".

Segundo conta Anyky, a associação tinha o foco na prevenção: "Tinha caixas de camisinha lá. Entendeu, a gente levava camisinha na rua, sabe? Pras meninas. Inclusive, eu levei camisinha". Em entrevista a Machado (2007:143), Walkíria deixa claro que esse era o foco principal da ASSTRAV: "a primeira meta da ASSTRAV era prevenção! Não se discutia política”. Walkíria me relatou que se lembra que pedia 24 caixas de camisinha, cada uma com 144 preservativos, e que a associação estimava, a partir desse trabalho que faziam, uma população de 800 travestis em Belo Horizonte. A aproximação da ASSTRAV com o movimento LGBT, e a participação na fundação da $\mathrm{ABGLT}^{5}$ foi o que fez com que a organização assumisse pautas "mais políticas", segundo depoimento de Walkíria a Machado (2007).

Anyky se afastou da ASSTRAV após algumas confusões que aconteceram na associação - um computador foi roubado, verbas foram desviadas. Anyky diz que nunca ficou muito claro o que aconteceu e que esses fatos levaram a uma briga entre Porcina $e$ Walkíria, e o consequente afastamento da Porcina da associação. Nas entrevistas que Machado (2007:147) realizou, Porcina assume ter pegado dinheiro da ASSTRAV, mas declara que era algo temporário e que iria devolver. Diz, também, que a associação sobrevivia principalmente de dinheiro que ela tirava do próprio bolso. Apesar de se afastar da militância, Anyky continuou a frequentar a sede da associação e acompanhar os acontecimentos.

Após a saída de Porcina, Walkíria La Roche assumiu a presidência da ASSTRAV e deu continuidade aos projetos. A associação realizava uma série de ações. Para Machado (2007) Walkíria dá destaque a duas como sendo de extrema importância:

${ }^{4}$ A data exata da fundação é controversa. Walkíria me afirma em entrevista que a fundação se deu em 1995; Machado (2007) afirma que a fundação foi em 1999. Essa diferença de datas talvez se explique pelo lapso temporal entre o início das atividades e a data do efetivo registro em cartório da organização.

${ }^{5}$ Associação Brasileira de Gays, Lésbicas, Bissexuais, Travestis e Transexuais. 
a distribuição de um "kit beleza" para travestis e transexuais que se prostituíam - o kit colocava numa pequena e prática embalagem itens de maquiagem, preservativos e um folheto explicativo sobre DST; e um trabalho de capacitação da polícia para lidar com as pessoas trans (Machado, 2007).

Em 1999, Walkíria foi até a polícia militar e reclamou da repressão perpetrada pela corporação e das revistas arbitrárias contra as pessoas trans. A partir dessa reclamação, surgiu a oportunidade de uma pequena fala num curso de formação de policiais. No ano seguinte, Walkíria já foi convidada a participar de um encontro internacional das polícias. Foi a partir desse contato da ASSTRAV com a polícia militar que, segundo me relatou Walkíria, a polícia teria começado a se reformular, e, de forma pioneira, o governo de Minas Gerais teria incluído na formação em Direitos Humanos dos novos policiais, um espaço específico para se falar sobre homossexualidades e pessoas trans. Esse é um trabalho de que Walkíria se orgulha e acha que foi pouco divulgado para a população ${ }^{6}$ :

\begin{abstract}
Walkíria: Então essa nova geração, eles não sabem. Os meninos estavam brincando assim. Falaram comigo hoje assim num grupo de whatsapp: "nossa Wal, ali no estação tem a polícia ali na porta do bar e como não tem um conflito? O pessoal fica sentado ali, sai bebendo, sai fumando, blablablá." É isso, isso não nasceu do nada.
\end{abstract}

Na entrevista que realizei, Walkíria ainda mencionou duas outras ações como sendo de extrema importância: uma formação de ensino fundamental para as travestis e transexuais da cidade,

\footnotetext{
${ }^{6}$ Walkíria julga essa ação como de grande importância, pois impediu efetivamente que os policias prendessem, arbitrariamente, as travestis $e$ transexuais que se prostituíam no Lourdes. Todavia, como relatado por Machado (2007:149), a polícia desenvolveu estratégias mais sutis, como estacionar o carro de polícia nos locais de prostituição, para conseguir expulsá-las. Essa ação teria sido responsável pela migração da prostituição para a Avenida Afonso Pena, onde até hoje permanece.
} 
por meio da exibição das fitas do Telecurso 2000, em parceria com a Fundação Roberto Marinho; e uma campanha de vacinação contra hepatite para as travestis que se prostituiam, em parceria com a infectologista Dra. Carmen Mazzili. A formação foi uma experiência que marcou Walkíria, serviu de grande aprendizado, mas que não deu muito certo.

\begin{abstract}
Walkíria: A gente viu a dificuldade e o desinteresse, porque elas falavam com a gente assim: "eu vou estudar para quê? Vou ser psicólogo e vou ter paciente? [...] Eu professora? Quem que vai estudar com a professora [trans]?" E não existia isso... E realmente a gente tomou um choque, porque eu vim de uma outra realidade, a Porcina veio de uma outra realidade.
\end{abstract}

Já a campanha de vacinação foi de grande sucesso, na opinião de Walkíria. Conseguiram vacinar um número grande de travestis que se prostituíam, principalmente na região da Pedro II e do Bonfim, por meio de uma articulação entre as donas de casa $^{7} e$ as redes informais de contato. Essa campanha teve uma repercussão grande na mídia, e a ASSTRAV chegou a organizar uma coletiva de imprensa. A reação da mídia foi bastante negativa, como relata Walkíria: "Os jornalistas quase me bateram lá, porque era caro a vacina. 'a senhora não sabe que é muito caro a vacina de hepatite?' Porque era primeira fala na vida que

\footnotetext{
${ }^{7}$ Donas de casa são, geralmente, travestis ou mulheres transexuais mais velhas, que possuem casas, e alugam quartos para outras pessoas trans, cobrando a diária. Essa figura ocupa um papel peculiar e, de certa forma, polêmico dentro do microcosmo trans. São comumente retratadas como "mães" e como "cafetinas". Por um lado, as donas de casa oferecem o único abrigo que muitas pessoas trans podem acessar; oferecem, ainda, proteção, cuidado e ajuda nos mais variados aspectos da vida (ajuda para denunciar violências em delegacia, para conseguir ingressar em uma política pública, para conseguir ir ao hospital ou posto de saúde, dentre outras). Por outro lado, é comum escutar denúncias de cobrança de ponto de prostituição, de agressão física e ameaça. Cada casa e cada dona de casa tem um perfil que pode variar bastante entre a "mãe" e a "cafetina" ou até conjugar as duas funções em diferentes momentos.
} 
as pessoas tinham que vacinar, como que você tava vacinando travestis, né?"

No entanto, o desvio de verba e outras confusões sujaram o CNPJ da associação, impossibilitando a captação de novas verbas. Além disso, Walkíria se afastou da organização, pois assumiu um cargo na prefeitura de Belo Horizonte e, posteriormente, no governo de Minas Gerais, no qual ficou até o final do governo Anastasia ${ }^{8}$. A conjunção desses fatores reduziu bastante a atuação da ASSTRAV, e, como veremos em outras entrevistas, fez com que a associação não tenha mais uma atuação forte e reconhecida.

Walkíria acredita que seu trabalho no governo estadual foi crucial para as políticas públicas LGBT em Minas e pioneiro no Brasil, mas que há uma antipatia do movimento, que se recusa a contar essa história. Quando perguntada sobre quais os projetos principais executados por sua gestão, Walkíria afirma que são vários, mas dá uma ênfase grande a questões de segurança pública. Segundo relata, as propostas de criação de um setor LGBT no Disque 100 Diretos Humanos, bem como a ideia de um curso nacional de formação para as políticas sobre temas relacionados aos Direitos Humanos das populações LGBT, foram apresentadas na $1^{a}$ Conferência Nacional de Segurança Pública, em 2009. Foi também nessa conferência que começou a ser desenhada a proposta de criação das alas LGBT nos presídios, hoje implementadas em Bicas e Vespasiano.

"Quem tá do lado de fora imagina que é um trabalho fácil, não é", afirma Walkíria. A implementação das políticas que planejava executar não era fácil. Ela relata ter tido apoio do governo, mas que havia uma série de dificuldades. As propostas não eram bem recebidas por alguns gestores, bem como a mídia $e$ setores conservadores da sociedade que protestavam contra suas ações. Ao propor a um diretor de presídio a distribuição de preservativos no interior da prisão, escutou a seguinte resposta: "A senhora tá louca? Isso aqui é um presídio de homi (sic), a senhora

8 Antônio Anastasia (PSDB/MG) governou o estado de Minas Gerais durante os anos de 2010 a 2014. 
quer que dê preservativos?". Foi, ainda, acusada por evangélicos de fazer apologia à homossexualidade nos presídios.

Walkíria avalia que seria possível avançar ainda mais, mesmo com toda a oposição, mas que não foi possível por falta de apoio do movimento social. "Isso é um retrocesso total, porque não avançou mais porque se a população não reconhecia aquilo, como é que você vai avançar com a política pública se você não tem do seu lado o movimento social apoiando e endossando aquilo?"

Apesar de afastada da ASSTRAV e da militância institucionalizada desde os escândalos do roubo do computador, Anyky continuou sendo uma pessoa de referência para a população de travestis e transexuais de Belo Horizonte, acolhendo pessoas com problemas de saúde, tirando outras da rua. $\mathrm{O}$ desligamento de Anyky da ASSTRAV parece ter gerado alguns atritos:

até então, enquanto eu estava na ASSTRAV, eu era uma senhora velha, que tinha uma casa, que acolhia as meninas. Aí depois que eu me desliguei de tudo, eu passei a ser uma cafetina exploradeira.

Anyky passou por diversos problemas com a polícia nesse período. Ela relata que, no meio da noite, a polícia batia $-e$ em uma ocasião até mesmo invadiu - a sua casa por denúncias de cafetinagem, tráfico de drogas e outras coisas mais. Essas ações polícias, no entanto, reaproximaram Anyky do movimento social $e$ acabaram por ter um efeito positivo: "Que eu acho realmente, que se alguém fez isso, a pessoa, se tiver morta, deve tá rolando na sepultura, né? E se tiver viva deve tá morrendo de ódio, porque ao invés de me destruir, acabou me dando visibilidade."

Nesse período, Anyky aproximou-se do CELlOS. A organização criou um núcleo específico para lidar com pessoas trans e suas demandas, e Anyky acabou sendo eleita vicepresidenta da associação. No início, pensou que estava sendo usada, como pode ser visto em sua fala abaixo: 
Eu achei que o CELLOS ia me colocar como uma bonequinha de presépio. Sabe, tem uma trans aqui, a gente adora ela, tem uma trans, tá alí... só que não sabiam que eu ia aparecer tanto, não sabiam que eu ia ficar tão conhecida, sabe... Eu não sei o que que é, que me deu tanta sorte, que eu apareci tanto e que as pessoas gostaram de mim, e que eu fui me aprofundando mais.

Talvez sua suspeita não fosse sem razão. Anyky, no momento da entrevista, ocupava o cargo de presidenta do CELLOS e é muito provável que esse cargo tenha criado oportunidades para participar de diversos espaços $e$ dê legitimidade a muitas das denúncias que faz, aos convites que recebe para dar palestras, como já o fez em cursos de formação de policiais. Todavia, quando perguntada sobre as ações que realiza e sobre quem a apoia nessas atividades, o CELLOS quase que desaparece e emergem outras organizações e pessoas.

Duas pessoas são fundamentais na militância de Anyky, Liliane Anderson e Maria Lúcia. Maria Lúcia era a vice-presidenta do Grupo Solidariedade - um grupo similar ao GAPA de apoio a pessoas soropositivas - e foi uma espécie de mentora política para Anyky. Era ela quem indicava quais órgãos podiam ser acionados em Belo Horizonte, quais reuniões deveriam ser frequentadas, pessoas que poderiam ser mobilizadas para resolver problemas, $e$ foi quem insistiu para que Anyky participasse das reunióes da coordenação municipal da DTS/AIDS. A coordenação se tornou uma grande parceira de Anyky e auxiliou a ativista no atendimento a uma série de questões de saúde.

Anyky: Mas se eu disser pra você que a entrada na saúde que mais me apoia, é a coordenação do DST/AIDS. Inclusive essa menina que foi internada, ela foi internada, $e$ ela ficou na ala feminina, você quer melhor do que isso? [Em] Qual hospital que existe isso? Mas eu ligo é pro pessoal daqui, da municipal. A hora que eu preciso, eles correm pra me ajudar. É uma grande parceria também. 
Hoje mesmo, eu estava lá, dando palestra pro pessoal lá do "Posso Ajudar", sabe?

Liliane Anderson foi responsável por apresentar Anyky ao movimento trans.

Anyky: "Não Anyky, eu vou te botar no movimento". Aí eu falei "ai Lili, que movimento é esse? Que negócio de movimento é esse?. Não!". Aí eu comprei um computador, já tinha comprado um computador. Aí ela "não, vou te adicionar as meninas, e num sei da onde, num sei da onde, num sei da onde... pra você conhecer". Aí foi quando ela me adicionou a Keila, Fernanda Benvenutty, sabe, e eu não sabia nem mexer em computador. E aí começou a adicionar uma, a outra, e num sei mais o quê.

A partir dessa aproximação, Anyky se tornou a representante da $\mathrm{ANTRA}^{9}$ em Minas Gerais e, apesar de não viajar para os encontros, acompanha e participa das discussões nacionais dessa associação. Lili também foi responsável por apresentar Anyky ao prof. Marco Aurélio Prado e seu núcleo, o NUH. ${ }^{10}$ Essa parceria, como conta Anyky, foi fundamental para sua atuação. Em 2011, Anyky participou do Encontro Regional Sudeste de Travestis e Transexuais, na cidade de São Paulo, candidatou Belo Horizonte para sediar o encontro do ano seguinte e sua proposta ganhou. $\mathrm{O}$ apoio para a realização do evento, no entanto, não veio do CELLOS e, sim, do NUH.

Anyky: Aí eu me candidatei e ganhei. Aí falei "que bom, agora eu ganhei". Fiquei igual doida, né? "Vamos ver como

\footnotetext{
9 A participação na ANTRA é simultânea à participação no CELLOS.

${ }^{10}$ Núcleo de Cidadania e Direitos Humanos LGBT. É um núcleo de estudos vinculado à Faculdade de Filosofia e Ciências Humanas da UFMG. Atualmente, é coordenado pelo prof. Marco Aurélio Máximo Prado, da psicologia, e desenvolve atividades de ensino, pesquisa e extensão relacionados às temáticas de gênero e sexualidade. Mais informações em:
} $<$ http://www.fafich.ufmg.br/nuh/> Acesso em: 11 dez. 2015 
que vai ser". Aí eu falei com o Marco: "ganhei! E como é que vai ser?". Quer dizer, quem fez tudo foi a UFMG, de cabo a rabo, quem fez foi o pessoal que ficou tudo doido lá, né?!, e faz papel daqui, faz papel dali... faz não sei mais o quê, e todo mundo achou que não ia acontecer, $e$ foi um dos encontros que mais foi falado, que todo mundo gostou.

A parceria com a UFMG foi fundamental para a realização $e$ o sucesso do evento, considerado um dos melhores já realizados. Dessa parceria surgiram outros frutos, como uma pesquisa para gerar dados estatísticos sobre a população trans de Belo Horizonte, que serviria para fomentar políticas públicas para as pessoas trans; e uma parceria com o Ministério Público de Minas Gerais (MPMG) para denunciar as violências e os assassinatos cometidos contra as pessoas trans em Belo Horizonte. O rosto de Anyky hoje está espalhado por toda a cidade em cartazes da campanha "Que diferença faz?" do MPMG. ${ }^{11}$

Fica claro que o CELLOS é secundário nessa atuação de Anyky no movimento trans. Talvez tenha sido o local que a acolheu institucionalmente, mas não são de lá os recursos financeiros e humanos para realizar suas ações. Anyky tem interesse em fundar uma ONG exclusivamente trans, chegou a pedir que eu revisasse o texto do estatuto, mas ainda não concretizou a fundação. Sente que não tem muito apoio e que as pessoas trans ainda têm pouca consciência da importância desse tipo de trabalho coletivo. Conta, um pouco decepcionada, que "é uma comunidade muito difícil, sabe, na hora de pedir socorro elas vêm com os braços abertos, mas na hora de se dispor pra ir nos lugares, elas não vão".

Apesar disso, Anyky tinha uma visão positiva sobre o contexto da época da entrevista. Percebe que muitos foram os avanços, nos últimos cinco anos: "Que não existia negócio de travesti dar palestra, de travesti ir na polícia dar palestra, de a

${ }^{11}$ Para mais informações sobre a campanha Que Diferença Faz? Ver: $<$ http://www.mpmg.mp.br/comunicacao/campanhas/que-diferenca-faz.htm> Acesso em: $11 \mathrm{dez} .2015$ 
gente se reunir e ir lá dentro do batalhão dar queixa... que as meninas estavam sendo ameaçadas. Entendeu?". Segundo Anyky, a violência policial reduziu, o atendimento ainda não é o ideal $e$ eles pecam por não investigar adequadamente os assassinatos, mas o espancamento cotidiano de travestis, prática comum da polícia em outras épocas, não acontece mais.

Assim como Anyky, Walkíria também possui um relação ambígua com o movimento LGBT misto. A ativista sempre colaborou com organizações mistas, mas diz que desde o início queria algo exclusivo:

Em 1995 eu já não queria estar tutelada a uma ONG gay, porque são especificidades completamente diferentes $e$ acaba não tendo esse entendimento. E percebi muito preconceito. Percebi e sofri...

\section{Carl e o MOOCA}

Carl e Gisella também iniciaram a sua atuação política em grupos mistos LGBT. Carl nem sempre militou pelas causas trans. Ele se aproximou do movimento em 2004, em função do antigo projeto SOMOS, da ABGLT, que capacitou lideranças por todo país. A atuação dele, na época, foi como liderança lésbica na cidade de Contagem, participando, inicialmente, do CELLOS Contagem $e$, posteriormente, fundando o MOOCA, uma dissidência do CELLOS. Em sua fundação, o MOOCA se chamava Movimento Organizado de Combate à Homofobia (MOOCAH), $e$ tinha como foco, principalmente, as questões de gays e lésbicas.

Carl não sabia que homens trans existiam, nem que poderia ser um. Foi a partir da sua inserção no movimento LGBT que conheceu o termo e outros homens trans $e$, segundo relata, começou a se perceber assim na primeira Conferência Nacional LGBT, confira:

Thiago: Você sabia [que era um homem trans] desde quando mais ou menos? 
Carl: Olha, desde a primeira conferência nacional LGBT, quando eu até conheci o Alexandre Peixe, né? Lá de São Paulo. Foi o Cristiano, aquele do CELLOS, aquele negro do CELLOS. Ele que me apresentou. Ele também já sabia e falou assim: "olha, pra mim, você é transexual" e tal, que não sei o quê. Isso foi 2008, né? Pouco antes disso. Aí que eu fui saber que isso existia, que eu não sabia. Eu não sabia. O movimento também não soube, só soube na conferência nacional através do Alexandre. Aí, falei assim: "nossa realmente eu sou isso, mas vai ser muito foda, né?". Minha família, minha namorada, né? Enfim... Aí, eu comecei a pesquisar na internet coisas do Buck Angel. É... $\mathrm{Na}$ época também tinha o Leonardo Tenório. Ele tinha um blog que falava tudo sobre transição, sobre questão de tratamento hormonal e tudo mais. Então, assim, eu fui através da internet lendo.

Apesar da descoberta naquele momento, Carl não começou a se apresentar imediatamente como homem trans, nem a militar nesse movimento. Vários fatores influenciaram nesse "atraso", um relacionamento considerado abusivo e, também, pressões do movimento para que continuasse como liderança lésbica. Carl relata que um ativista gay chegou a agradecê-lo por não ser homem trans, pois assim não "roubaria" vaga dos homens gays na conferência.

A aproximação dele com o movimento trans foi mais recente, a partir de sua transição. Carl relata que já conhecia o movimento trans por causa de sua militância LGBT; conhecia a ASSTRAV e a Xuxa, militante do CELLOS. Todavia, acreditava que não estavam propriamente organizados. $\mathrm{Na}$ opinião dele, quem era do movimento LGBT não conhecia muitas das demandas e até dos termos que o movimento trans utiliza. Foi em 2013, em uma reunião organizada em função do cancelamento da Parada LGBT da Contagem, que Carl e outras pessoas do movimento LGBT entraram em contato com o movimento: 
Carl: Na verdade é uma coisa que a gente tava lembrando esses días: foi nas jornadas de 2013, que teve é aquele cancelamento da parada LGBT, a gente fez uma reunião contra o cancelamento da parada, que era o período que a gente acha que deveria ter, foi a primeira vez que a gente escutou o termo cis. A gente que era do movimento LGBT, a gente não sabia. Então, foi primeiro contato que a gente teve com esse movimento trans; foi com a Sofia, na época a Ariane defendia a bandeira, aquelas meninas que hoje são radicais feministas. Então esse foi o primeiro contato que eu tive com essa emancipação do movimento, que a gente foi saber das letrinhas ftm, mtf, cis; não binário a gente já tinha escutado, então foi em 2013. E a partir daí a gente falou assim, "a gente até precisa fazer um curso de formação", porque eu nem sabia o que é isso. O Gustavo também não sabia, e a gente foi muito humilde e a gente falou: "a gente não sabe o que vocês tão falando". Aí que a Sofia explicou pra gente e ela, assim... ela ajudou muito.

A transição de Carl e essa aproximação com aquilo que chama de movimento trans na perspectiva da emancipação, fizeram com que o MOOCA desse uma virada, retirando o $\mathrm{H}$ de seu nome e ampliando sua luta. O MOOCA foi uma organização mista, que contava com a participação de gays, lésbicas e outras pessoas trans, mas que se distanciou do movimento LGBT que considerava tradicional, como o CELLOS. Na opinião de Carl, essas organizações teriam o foco principal nas pautas gays, tanto que o chamavam de forma jocosa de movimento GGGG, mas o MOOCA operaria uma inversão na hierarquia das pautas, trazendo à tona pautas das "letrinhas" mais invisibilizadas, como as das pessoas bissexuais e, principalmente, das pessoas trans. Como ele mesmo declara, "eu tenho muito orgulho do meu coletivo porque é um coletivo LGBT que essas pautas são todas trans".

A sede do MOOCA se localizava em Contagem, na região metropolitana de Belo Horizonte, mesma cidade em que Carl ainda reside. Apesar disso, a organização e o ativista têm atuação forte na capital e começaram a ganhar uma visibilidade grande em todo o estado e no país. Sua organização realizava uma série de 
ações e parcerias na cidade, participava de espaços de diálogo do movimento com o Estado e atua "fazendo pressão" - à época da entrevista o MOOCA fazia pressão na Secretaria Estadual de Saúde e na Municipal de Belo Horizonte para a reabertura do Ambulatório Trans ${ }^{12}$, que se localizava no Hospital das Clínicas de Belo Horizonte. Segundo Carl, o governo fazia promessas nesse sentido:

Carl: [...] a gente tem o compromisso do Estado, na pessoa da Maria Turci [atual superintendente de Atenção Primária a Saúde do Governo do Estado de Minas Gerais], que talvez não seja com o nome de ambulatório, mas atendimento vai existir. Inclusive a intenção deles é que seja nos micropolos, né? Que não seja só na capital. E que a cirurgia deve voltar a ser feita aqui na, aqui em $\mathrm{BH}$, com o pessoal do interior fazendo aquele TFD, né? Que é transporte, eu não sei qual que é a sigla, mas é pra transportar e vim fazer a operação aqui. Esse é o compromisso que a gente tem do Estado, mas isso foi através de um abaixo-assinado que a gente fez, uma pressão.

\footnotetext{
${ }^{12} \mathrm{Na}$ realidade, até o momento de realização da entrevista, não havia existido um Ambulatório Trans em Belo Horizonte. Se tem notícias de que cirurgias foram feitas nos anos 2000, de forma experimental, mas, até onde é falado no movimento, não se tratou de uma política sistemática. Recentemente, por pressão do Paulo Bevilacqua e iniciativa de algumas médicas do Hospital das Clínicas que são professoras da UFMG, iniciou-se a tentativa de criar um ambulatório trans. O procedimento de criação e cadastramento desse ambulatório para a autorização de realização de todos os procedimentos, bem como o recebimento de verba derivada do Ministério da Saúde, é bastante complexo e demorado. Por essa razão, as médicas, por iniciativa própria, iniciaram alguns atendimentos preliminares, principalmente no que diz respeito ao atendimento endocrinológico. Todavia, após conflito entre a equipe $e$ algumas ativistas travestis, que denunciavam que o ambulatório era excludente e só atendia transexuais, os atendimentos foram suspensos e o processo de criação paralisado. Ao final de 2017 finalmente houve a abertura de um ambulatório do processo transexualizador em Belo Horizonte, mas em outro hospital e com outra equipe.
} 
A saúde era uma das pautas prioritárias para o MOOCA. O mau atendimento na saúde faz com que as pessoas trans procurem tratamentos alternativos e automedicação, como diria Carl: "Um monte de gente que procura [tratamentos alternativos] porque não quer ir no médico, fala assim: 'ah eu não vou no médico para ser hostilizado'”. Existem comunidades na internet em que as pessoas trocam informações sobre como se tratar, como se hormonizar. Esse tipo de automedicação pode acarretar problemas de saúde nas pessoas, como aconteceu com o próprio Carl, que teve um início de cirrose em função da hormonização incorreta.

A pauta da saúde é uma pauta complexa. Demanda abertura de serviços novos, mas também a capacitação dos(as) profissionais para lidar com as pessoas trans - desde os/as atendentes, que devem respeitar o nome social, até os/as médicos, que muitas vezes não sabem as especificidades do tratamento de uma pessoa trans. Carl enfatiza que não é só na questão da transição; pessoas trans também possuem outros tipos de demanda e querem ser respeitadas na hora de buscar um posto de saúde por outras causas.

Relacionada à saúde havia, também, a demanda pela despatologização da transexualidade. No momento da entrevista, estava em vigor a Classificação Internacional de Doenças (CID-10) que classificava a transexualidade como um transtorno mental (F64.0) (Leite Jr., 2011; Teixeira, 2013), todavia Carl acreditava que isso é um equívoco. Na sua opinião, a patologização da transexualidade tira do sujeito a autonomia sobre o seu próprio corpo e o MOOCA atuou para difundir os debates sobre a despatologização na cidade e nos serviços de saúde.

A atuação do MOOCA também se dava em outras frentes e com outras parcerias. Atuavam formando outros militantes através de cursos de formação com a participação de acadêmicos $e$ ativistas. Se preocupavam bastante com a empregabilidade das pessoas trans, que, segundo Carl, muitas vezes têm na prostituição a única opção, por isso buscaram, sem sucesso, aprovar um 
projeto de economia solidária com foco na geração de renda para pessoas trans.

O MOOCA fez, ainda, uma parceria com a faculdade de direito da $\mathrm{UNA}^{13}$, que começou a prestar atendimento jurídico gratuito as pessoas trans. Como conta Carl, a UNA ingressou com ações para retificação de nome e gênero para um grupo de pessoas trans e tentaram replicar essa iniciativa em outras faculdades, como a Pitágoras ${ }^{14}$. O grupo possuiu parceria com diversos diretórios acadêmicos e coletivos estudantis, seja por proximidade ideológica ou político-partidária. Nos casos específicos do Diretório Acadêmico de Medicina e do Diretório Central dos Estudantes (DCE), ambos da UFMG, a parceria se deve ao fato de um dos integrantes do MOOCA ser simultaneamente integrante dos dois diretórios.

Quando perguntado sobre outras organizações e outros ativistas, Carl informou que existe uma atividade forte na internet, pessoas que muitas vezes não são vinculadas a qualquer associação, mas que mantêm uma atuação por meio de postagens em blogs, em grupos do facebook. A influência da internet é marcante para Carl, grande parte do que aprendeu sobre o movimento trans, ele credita a Daniela Andrade, uma das ativistas que atuam principalmente na internet, e a qual ele considera uma teórica do movimento trans.

Carl avaliava o cenário com certo ceticismo. Reconhecia que existiram algumas conquistas nos últimos anos, como um diálogo maior com o governo do estado, principalmente por meio da Coordenadoria de Diversidade Sexual (CODS), a garantia de vagas de pessoas trans nas conferências LGBT municipal $e$ estadual - para Carl, isso foi uma derrota do movimento GGGG -, a regulamentação do nome social nas escolas e faculdades, $e$ percebia que a maior visibilidade é, também, uma grande

${ }^{13} \mathrm{O}$ Centro Universitário UNA é uma grande faculdade privada de Belo Horizonte e região metropolitana.

${ }^{14}$ A Faculdade Pitágoras é uma das grandes faculdades privadas de Belo Horizonte com campus espalhados por várias regiões da cidade e na 
conquista. No entanto, acreditava que muitos dos avanços eram só paliativos: "conversar até Hitler conversava. A gente precisa ver é as coisas sendo efetivadas". Para ele, há mais retrocessos do que avanços e creditava isso ao avanço do conservadorismo.

\section{Gisella, Bruno, o IPR e o IBRAT}

Gisella e Bruno foram mencionados nas outras entrevistas como pessoas que estavam se destacando no ativismo trans em Belo Horizonte. Eu já conhecia os dois e entrei em contato com eles pelo facebook perguntando, individualmente, se aceitariam me conceder uma entrevista. Ambos aceitaram imediatamente, mas, de início, não marcamos uma data. No dia seguinte ao meu contato, Bruno enviou uma mensagem dizendo que o dia que eu marcasse com a Gisella, poderia marcar com ele também. Eu não havia informado a nenhum dos dois que entrevistaria o outro, mas como são amigos e trabalhavam no mesmo lugar, provavelmente conversaram sobre isso. Aceitei a proposta ${ }^{15}$ e, no dia 09 de dezembro, fui até o $\mathrm{IPR}^{16}$, local de trabalho deles, para entrevistálos. Achei estranho entrevistá-los no local de trabalho, mas ambos se sentiram mais confortáveis dessa maneira. Além disso, me informaram que o IPR tem o costume de liberar para algumas atividades, como dar entrevistas e proferir palestras.

Gisella iniciou sua militância por volta dos anos 2000, quando ainda morava em Montes Claros, e foi uma das fundadoras do Movimento Gay das Gerais (MGG) naquela cidade.

${ }^{15}$ Aceitei a proposta, também, como uma forma de experimentar com outros formatos de entrevista, uma entrevista coletiva. Foi uma experiência diferente e bastante difícil. Penso que consegui algumas informações que não conseguiria em entrevistas individuais, como algumas discordâncias que aparecerão neste texto. Por outro lado, percebi que não me aprofundei tanto na atuação de cada uma das pessoas como faria se as entrevistasse separadamente. A diferença na personalidade dos entrevistados, Gisella é mais extrovertida e Bruno mais tímido, também influenciou bastante a dinâmica da entrevista. Gisella claramente falou muito mais que Bruno. Talvez a entrevista individual tivesse sido mais produtiva para extrair informações de Bruno.

${ }^{16}$ Instituto Pauline Reichstul. 
O grupo articulou-se, inicialmente, a partir de alguns projetos do GAPA, que trabalhavam com a prevenção do HIV/AIDS entre homens que fazem sexo com homens e travestis. À medida que o projeto se desarticulou e alguns problemas com o GAPA surgiram, algumas pessoas, que sentiam a necessidade de fundar sua própria ONG, se reuniam em bares à noite e, assim, fundaram o MGG.

Gisella acredita que foi um erro escolher esse nome e que ele deveria ser trocado: "Eu deixei isso passar [...] eu aprendi isso com a Lili, a instituição tinha que ser uma instituição de travestis, era uma associação de travestis, mas eu não tive esse apoio". O contato com Liliane Anderson, a Lili, se deu anteriormente, em função do GAPA. Por convite de Lili, Gisella viajou ao Espírito Santo - onde Lili morava e militava à época - para participar de um encontro do movimento trans. Nesse encontro, Gisella teve seu primeiro contato com as lideranças nacionais do movimento, como Keila Simpson, Hannah Suzart, Janaína Lima e outras. ${ }^{17}$

A mudança para Belo Horizonte afastou Gisella do movimento. A reaproximação se deu quando sentiu que não queria mais se prostituir e buscou um trabalho formal. Encontrou um emprego no Centro de Referência de Direitos Humanos (CRDH), um projeto do IPR que, inicialmente, não tinha foco nas pessoas trans, mas a demanda foi tão grande que acabaram sendo incluídas como um novo público-alvo. O sucesso do centro, na opinião de Gisella, se deu por vários motivos, mas, principalmente, pela localização, na Avenida Pedro II, local

${ }^{17}$ Keila Simpson é uma travesti radicada em Salvador. É uma das principais lideranças da ANTRA, ocupou o cargo de presidenta dessa organização entre 2004 e 2008. A época da entrevista ocupava, mais uma vez, o cargo de presidenta da ANTRA para a gestão 2016-2020. Janaína Lima é uma travesti com forte atuação no estado de São Paulo. Foi uma das integrantes do Grupo Identidade de Campinas e já compôs o Conselho Fiscal da ANTRA. Mesmo nunca ocupando cargos de destaque em organizações nacionais, é considerada uma grande liderança nacional. Hanna Suzart foi uma das principais lideranças do movimento trans no Rio de Janeiro, fundou o grupo ASTRA Rio, grupo que ainda se encontrava em atividade até o fechamento dessa pesquisa. Hanna Suzart faleceu em 2006 por consequências da AIDS. 
frequentado por diversas travestis e mulheres transexuais. Sua presença ali também foi outro fator significante para esse sucesso. Como Bruno e Anyky lembraram, as pessoas passavam na porta, viam Gisella sentada e se identificavam, por isso, sentiam-se confortáveis para entrar. Por ter experiência na prostituição e por ter passado recentemente pelo processo judicial de retificação de nome e gênero, ela acredita que conseguia compreender melhor as demandas e preocupações das pessoas trans que buscavam o centro, o que facilitava a abordagem, o diálogo e o acompanhamento. Gisella diz que deu sorte porque recebia para fazer o que gosta.

O militante com a trajetória mais recente que entrevistei foi o Bruno. Sua primeira aproximação com o movimento se deu há dois ou três anos antes de nossa entrevista, quando começou a buscar informações para iniciar a hormonização. Diz que, na época, entrou em contato com o prof. Marco Aurélio, da UFMG, $e$ com a Dalcira Ferrão ${ }^{18}$, que passaram algumas informações a ele e o apresentaram ao movimento. No entanto, sua militância não começou nesse momento. Foi com a entrada no $\mathrm{CRDH}$ do IPR que Bruno começou a militar.

$\mathrm{Na}$ época da entrevista, Bruno representava o $\operatorname{IBRAT}^{19} \mathrm{em}$ Minas Gerais. Contou que já participava do IBRAT há algum tempo, mas fortaleceu o vínculo no início de 2015, quando participou, em São Paulo, do I Encontro Nacional de Homens Trans. Em Minas Gerais, e em especial em Belo Horizonte, o IBRAT ainda não atuava muito. "Nós estamos meio perdidos", diz Bruno.

A atuação dos dois é difícil de classificar - será militância ou emprego? Muito do que fazem é em função de seu emprego, frequentam espaços de discussão e decisão representando o IPR,

\footnotetext{
${ }^{18}$ Dalcira Ferrão é psicóloga e ativista bissexual de Belo Horizonte. Além disso, já ocupou o cargo de psicóloga do Centro de Referência LGBT municipal, integrou diversas ONGs, como o CELLOS Contagem, e foi responsável pela criação da Comissão de Psicologia, Gênero e Diversidade Sexual do Conselho Regional de Psicologia de Minas Gerais.

${ }^{19}$ Instituto Brasileiro de Transmasculinidades.
} 
mas é perceptível que esses convites surgem pelo fato de serem pessoas trans muito articuladas, com falas claras e que dominam as demandas do movimento. Tanto Gisella quanto Bruno eram frequentemente convidados para dar palestras em faculdades. Relatam já terem ido à UNA, a diversos campi da PUC, à UFMG, entre outras instituições de ensino, convites similares aos feitos a Carl e Anyky. Isso demonstra que, apesar do IPR e seus trabalhos ali serem fundamentais para a visibilidade que conquistaram, os convites que recebiam pouco tinha a ver diretamente com a atuação do IPR.

\begin{abstract}
"É bem interessante, né? Porque nós dois não temos ainda a oportunidade de entrar para uma faculdade como estudantes, mas a gente vai na faculdade para ensinar os outros", brinca Bruno.
\end{abstract}

Tanto Gisella quanto Bruno avaliavam que a educação é uma das pautas principais do movimento trans. Querem ocupar espaços nas universidades palestrando, mas também como alunos(as). Querem que as universidades se encham de pessoas trans. Gisella julga que isso é importante porque as pessoas conhecem apenas um lado das travestis, o negativo, mas que, a partir dessa atuação, podem conhecer outros, conhecer suas demandas. Além disso, percebe que a educação está vinculada a outra demanda, por emprego. A prostituição, na opinião de Gisella, deve ser uma opção, e não um destino para as travestis. Ela afirma que sonha em ver uma travesti falando que é advogada, mas que se prostitui porque quer.

No período que o $\mathrm{CRDH}$ existiu, realizou uma série de ações específicas para as pessoas trans. Realizava um espaço de debate, chamado Chá das Trans, em que convidava alguém, muitas vezes pesquisadores do $\mathrm{NUH}$, para palestrar. Em parceria com a Defensoria Pública de Belo Horizonte, atendia e encaminhava pessoas trans que desejavam retificar seus documentos, dando abertura ao processo. Juntamente à coordenação de DST/AIDS, participava de atividades de prevenção. 
O centro de referência realizava, ainda, diversas ações voltadas para outros públicos, como as pessoas em situação rua. Gisella e Bruno afirmam que as questões das pessoas trans acabavam por atravessar todas as atividades do centro, mesmo quando essas não eram o foco:

Gisella: mesmo a gente não falando da nossa pauta, a gente é pauta em qualquer lugar que a gente esteja, a presença já faz uma figura importante. É uma militante mesmo involuntária.

Bruno: Só de existir, a gente já tá militando.

O CRDH acabou, mas o IPR ainda manteve Bruno e Gisella contratados por um tempo. Ambos avaliam que isso aconteceu pelo fato de o trabalho realizado por eles ter conquistado uma grande visibilidade na cidade. Após o fim do contrato, Gisella foi contratada pelo governo estadual.

Gisella não é filiada a nenhuma organização do movimento LGBT. Conhece a ASSTRAV de nome, sabe que é um nome antigo na cidade, tendo morado com Porcina no período que essa atuava na ASSTRAV, mas não vê atuação do grupo hoje e não se sente representada. Ela também é crítica à atuação de outras ONG e diz:

Gisella: primeiro que eu tenho essa cisma, esse medo de me afiliar, primeiro porque não me sinto representada dentro de algumas ONGs, que eu vejo que elas são muito GGGG. Não me sinto representada, nem contemplada, mas respeito e sei da importância de cada uma.

Gisella se considera ativista independente e tem medo de se associar, prefere ocupar vários espaços. "O movimento está muito desorganizado, está muito rachado, por questões partidárias", avalia.

Além da atuação no IPR e da participação no IBRAT, Bruno tinha uma atuação forte na internet, coordenando alguns grupos 
de Homens Trans, em parceria com Carl e Raul Capistrano. Bruno contou que possuía um grupo em que postavam fotos de suas cirurgias para comparar resultados, informavam quem foi o médico que fez, a técnica utilizada, se foi necessário laudo patológico. Em suma, compartilhavam suas experiências $e$ as avaliavam, para que as outras pessoas consigam o melhor resultado possível e evitem passar por experiências negativas. $\mathrm{O}$ grupo também servia para organizar algumas ações coletivas, como um escracho na internet ou similares.

Quando perguntados sobre uma possível separação do movimento trans $e$ do movimento LGBT, os dois mostraram pequenas divergências. Gisella toma uma posição de maior agregação, acredita que os movimentos devem se unir cada vez mais. Para ela, a estratégia deve ser a ocupação cada vez maior de espaços pelas pessoas trans, conscientizando as outras pessoas sobre suas demandas. A participação de pessoas trans nas organizações é fundamental para Gisella, que acredita que um grupo sem pessoas trans dificilmente defenderá pautas que não sejam só gays. Bruno, por sua vez, acredita que a separação é algo desejável, "são pautas realmente bem diferentes", afirma. No entanto, por uma avaliação estratégica, pensa que a separação significaria a morte do movimento trans. Na sua opinião, há pouca uniáo e pouca força: se já ocupam pouco espaço, caso se separassem ocupariam menos ainda.

Gisella e Bruno percebiam avanços recentes. Para os dois, as conferências municipal e estadual LGBT foram marcantes $e$ aprovaram importantes demandas de políticas públicas específicas para as pessoas trans. Assim como Carl, consideram que a conquista das vagas reservadas para pessoas trans, e em especial a vaga para homens trans, como uma vitória para o movimento trans, para uma representação maior de suas demandas. Essa não foi uma vitória fácil, e dizem que havia muita gente nas conferências que não queria que essas vagas fossem aprovadas.

A criação do Conselho Estadual LGBT também é vista como um avanço necessário. É uma demanda histórica do movimento social LGBT no estado de Minas Gerais que ganhou forças em 
2015 com a proposição do Projeto de Lei 1831/2015 pela Deputada Marília Campos (PT). Na opinião de Gisella, quando o conselho for efetivamente criado e implementado servirá como um espaço importante para lutar por políticas públicas. A militante, inclusive, se informou sobre o procedimento de criação $e$ de eleição previsto no projeto e reclamou da paridade entre governo e sociedade civil. Na sua opinião, o movimento social deveria ter uma representação maior, diferentemente da proposta.

Gisella reconhece que a maior visibilidade é uma conquista grande. Bruno ironiza e fala que homens trans, agora, estão na moda. Gisella discorda, acredita que até pode ser moda, mas vê além, percebe que as pessoas trans estão ocupando mais espaço $e$ que isso, na sua opinião, é muito importante. Nesse ponto, agradece o apoio de universitários, que estão pegando para si a pauta e levando para outros lugares.

Apesar desses avanços, muitas coisas ainda não são adequadas. A questão da saúde aparece como uma das pautas principais, ao lado da educação e do trabalho, e o relato de Bruno ressoa o que Carl e Anyky já tinham informado.

Bruno: Uma coisa que acontece muito com a gente: a gente pode estar morrendo de passando mal, a gente deixa de ir no médico porque sabe que não vai ser respeitado. Pelo menos para mim, quando eu peguei a identidade nova, eu disse: Primeira coisa, eu vou no médico. Não interessa o que que eu tenho, qualquer um, não sei pra que serve, mas eu vou.

Bruno percebe, ainda, que não houve muito avanço na medicina. Relata que as dúvidas que escuta de homens trans, $e$ até mesmo dos médicos, são as mesmas que seu amigo, Raul Capistrano, tinha há anos, quando começou a se hormonizar. Na opinião dos dois, o sistema de saúde de Belo Horizonte tem muito a melhorar em seu atendimento. Relataram a existência de uma portaria garantindo o uso do nome social no atendimento, existiria até mesmo um cartão impresso com o nome social, mas que não 
era respeitado. Segundo relatam, a própria Anyky, que está em cartazes sobre o nome social em todo posto de saúde, já foi desrespeitada. A criação do Ambulatório Trans seria, na opinião de Gisella, uma forma de ajudar na solução desse problema.

Avaliaram que a prefeitura deveria melhorar a forma com que lida com pessoas trans. A prefeitura teria algumas funcionárias travestis, mas que não têm seu nome social respeitado. $\mathrm{O}$ único atendimento específico para pessoas trans, na prefeitura de Belo Horizonte, ocorria no Centro de Referência LGBT, mas era avaliado como não adequado e não suficiente. Primeiro por não ser tão acessível, ficava localizado em um prédio do governo onde é necessário apresentar a identidade para o porteiro, o que pode afastar algumas pessoas trans que não retificaram seus documentos. O atendimento lá não seria capacitado para tratar com pessoas trans; Bruno reclama que foi tratado como se fosse homossexual e não uma pessoa trans. Além disso, o centro seria mal divulgado e deveria prestar mais serviços, como o atendimento jurídico gratuito. Outro exemplo do descaso da prefeitura com a população trans seria o nome do programa " $\mathrm{BH}$ Sem Homofobia"; Bruno e Gisella não se sentiam representados por esse programa e acreditavam que deveria mencionar a transfobia também.

Questões da conjuntura política nacional também foram apontadas como retrocesso por Bruno e Gisella. Mencionaram a atuação de setores conservadores, no Congresso Nacional, para aprovar projetos de lei reacionários - como o que proibiria a venda da pílula do dia seguinte - e para impedir a aprovação ou até mesmo o andamento dos projetos que garantiriam os direitos das pessoas trans, como o PL João W. Nery.

\section{Costurando as histórias para concluir}

De uma forma livre, e percorrendo as histórias de cinco pessoas, procurei contribuir para o campo de estudos do movimento de pessoas trans, com um foco específico na cidade de Belo Horizonte. Corroborei achados das pesquisas de Machado 
(2007) e Carvalho (2011, 2015; Carvalho; Carrara, 2013), mas avancei. Em relação ao primeiro, avancei no que diz respeito ao foco no movimento trans e na amplitude temporal; em relação ao segundo, avancei focalizando no contexto local da cidade de Belo Horizonte.

Demonstrei que as fronteiras entre o movimento trans $e$ LGBT são borradas, grande parte das pessoas entrevistadas inicia sua atuação no movimento LGBT e algumas, como Carl e Anyky, até hoje fazem parte de associações mistas. No entanto, há sinais de uma emancipação maior do movimento trans nos últimos anos $e$ a consciência de se tratar de coisas relativamente diferentes. A maioria dos entrevistados é contra uma ruptura completa dos movimentos, mas reconhece que certo distanciamento tem sido necessário. São pautas diferentes, mas pautas irmãs, como colocado por Carl.

Não encontrei organizações institucionalizadas exclusivamente trans, ainda em atividade, em Belo Horizonte. O nome ASSTRAV, tão marcante no passado, ainda é mencionado algumas vezes, mas não há sinais de que esteja atuante. O que percebi foram representantes de redes nacionais exclusivamente trans, como o IBRAT e a ANTRA, que aqui atuam, podendo conjugar essa atuação com a vinculação a alguma associação local, como no caso de Anyky, ou não, como no caso de Bruno.

Durante os anos de 2015 e 2016, surgiu em Belo Horizonte, e por todo o Brasil, uma série de iniciativas de cursinhos prévestibulares para estimular $\mathrm{o}$ ingresso de pessoas trans na universidade. Até a conclusão deste artigo, existiam dois cursinhos desses em $\mathrm{BH}$, o Transvest $^{20}$ e o Transenem ${ }^{21}$, que reúnem dezenas de pessoas trans. Esses espaços são organizados de forma independente por diversas pessoas cis e trans, mas contam com o apoio das pessoas entrevistadas, principalmente Carl, que é muito

\footnotetext{
${ }^{20}$ Para mais informações: < https://www.facebook.com/transvest $>$ Acesso em: 18 jul. 2016.

${ }^{21}$ Para mais informações: < https://www.facebook.com/transenembh > Acesso em: 18 jul. 2016.
} 
envolvido com o Transvest. Apesar de o foco ser no estudo para a aprovação no vestibular, esses espaços acabam aproximando as/os estudantes de ativistas e, também, incentivam a participação em eventos de caráter político na cidade. Acredito que esses espaços servirão como uma incubadora de novos(as) ativistas trans em Belo Horizonte e é possível que novos coletivos e organizações surjam a partir daí.

Nas falas, uma série de demandas são apresentadas, mas fica clara a centralidade de questões de saúde, como hormonização e cirurgias diversas para readequação de seu corpo. No entanto, quase todos alertam: não é só isso! As pessoas trans também têm dores de cabeça, diarreias e problemas de saúde comuns. A demanda é por um atendimento integral à saúde, respeitando a autonomia dessas pessoas sobre si. Isso implica em respeitar o seu nome e seu gênero, utilizando o nome social quando a pessoa ainda não retificou juridicamente seus documentos.

Outras demandas variadas vão de facilitação da retificação do nome e gênero na justiça, acesso à educação até o fim da violência e da discriminação. $\mathrm{O}$ trabalho parece ser outro ponto crucial. Mesmo que brevemente, todas as entrevistas relataram dificuldades das pessoas trans para conseguir emprego, o que, segundo diagnóstico dessas próprias pessoas, acabaria as pressionando para a prostituição.

Talvez em função das diversas demandas, as estratégias do movimento também são variadas, tomando formas mais ou menos institucionalizadas a depender de quem e do objetivo. Walkíria, no início de sua atuação, apostou na execução de um projeto de intervenção $e$, na sequência, se tornou uma "femocrata", ingressando no Estado para trabalhar na promoção de políticas públicas LGBT. Carl, Anyky e Gisella atuavam muito "fazendo pressão" no Estado, participando de reuniões, de espaços de participação, como conselhos e comitês, enviando ofícios cobrando a atuação e demandando políticas públicas, organizando protestos, etc. 
Outras formas mais micropolíticas de atuação também apareceram fortemente. O grupo de Carl fazia memes para ironizar gestores que atuavam contrariamente aos interesses de suas organizações. Já Bruno mantinha redes de compartilhamento de informações na internet. Essas redes, em que Carl também participava, são importantíssimas para que os homens trans aprendam a se hormonizar, descubram quais profissionais são bons e quais são ruins, em suma, facilitam, enormemente, a vida das pessoas trans. Talvez muitas dessas pessoas nem seriam quem são sem o acesso a essas redes.

Independentemente da organização, percebi que $\mathrm{O}$ movimento atuava muito por meio de parcerias. A parceria com as universidades se mostrou fundamental em todas as entrevistas $e$ tomou diversos formatos, auxiliando Anyky a organizar um evento, criando um serviço de atendimento jurídico gratuito por pressão de Carl, dentre outros tipos de parceria.

Foi possível perceber que, desde o início do movimento, a AIDS é um fator relevante e dela surgem parcerias fundamentais. Foi através do GAPA que Anyky e Walkíria iniciaram o ativismo e, na década de 1990, fundaram a ASSTRAV. Atualmente, a AIDS perdeu a centralidade que já teve, mas continua influente, como fica claro na experiência de Anyky. É com a coordenação municipal de DST/AIDS que conseguia apoio na área da saúde, $e$ foi uma militante do grupo Solidariedade que a auxiliou a conseguir essa articulação na prefeitura.

Esta pesquisa, no entanto, não esgotou o campo e consigo vislumbrar uma série de fios soltos que poderiam ser explorados. Primeiro, é preciso me aprofundar, ainda mais, na atuação da ASSTRAV e entender a atuação desse grupo, tanto no passado quanto na atualidade. Dessa maneira, novas entrevistas com Walkíria La Roche e Porcina seriam valorosas, mas também entrevistas com outras militantes dessa organização, como Luíza Ferreira e Adriana Kelvin. Segundo, a emergência dos cursinhos pré-vestibulares me parece algo de extrema importância e que terá um impacto definitivo no campo. Seria interessante aprofundar no conhecimento de suas estruturas organizacionais e em como os 
atores e atrizes circulam desse espaço para outros. Terceiro, foi perceptível que, como Mário Carvalho (2015) já apontava, há um campo de militância forte na internet e que essa é fundamental, principalmente para a nova geração de pessoas trans. Seria interessante compreender melhor como isso se articula em Belo Horizonte. Quarto, há uma curiosa similaridade entre as histórias do movimento trans e do movimento de prostitutas em Belo Horizonte. Apesar de similares, essas histórias não se cruzaram nas minhas entrevistas, esses pontos de contato merecem ser melhor investigados. Por último, seria interessante, ainda, a utilização de técnicas diferentes, por exemplo, pesquisas documentais poderiam contribuir para um aprofundamento da história aqui contada, ao investigar arquivos de jornais com notícias sobre o movimento.

\section{Referências bibliográficas}

AlmEIDA, G. "Homens trans": novos matizes na aquarela das masculinidades? Revista Estudos Feministas, Florianópolis, vol. 20, n 2, ago. 2012, pp.513-523.

Alonso, A. As teorias dos movimentos sociais: um balanço do debate. Lua Nova, $\mathrm{n}^{\circ}$ 76, São Paulo, 2009, pp.49-86 [http://dx.doi.org/10.1590/S0102-64452009000100003 - acesso em: 1 jul. 2015].

AlvareZ, S. E. Para além da sociedade civil: reflexões sobre o campo feminista. cadernos pagu (43), Campinas-SP, Núcleo de Estudos de Gênero-Pagu, dez. 2014, pp.13-56 [http://dx.doi.org/10.1590/01048333201400430013 - acesso em: 6 set. 2015].

ÁviLA, S. Transmasculinidades: a emergência de novas identidades políticas e sociais. Rio de Janeiro, Multifoco, 2015.

BENTO, B. A reinvenção do corpo: sexualidade e gênero na experiência transexual. Rio de Janeiro, Garamond Universitária, 2006.

BROWN, E. H. Trans/Feminist Oral History: Current Projects. TSQ: Transgender Studies Quarterly, vol. 2, n 4, nov. 2015, pp.666-672 [https://doi.org/10.1215/23289252-3151583 - acesso em: 8 jan. 2016]. 
CARVAlHO, M. Que mulher é essa? Identidade, política e saúde no movimento de travestis e transexuais. Dissertação (Mestrado em Saúde Coletiva), Instituto de Medicina Social, Universidade do Estado do Rio de Janeiro, Rio de Janeiro, 2011.

CARVAlHO, M. "Muito prazer, eu existo!": visibilidade e reconhecimento no ativismo de pessoas trans no Brasil. Tese (Doutorado em Saúde Coletiva), Instituto de Medicina Social, Universidade do Estado do Rio de Janeiro, Rio de Janeiro, 2015.

CARVAlHO, M.; CARRARA, S. Em direção a um futuro trans? Contribuição para a história do movimento de travestis e transexuais no Brasil. Sexualidad, Salud y Sociedad - Revista Latinoamericana, vol. 0, ${ }^{\circ}$ 14, Rio de Janeiro, 5 ago. 2013, pp.319-351. [https://www.epublicacoes.uerj.br/index.php/SexualidadSaludySociedad/article/view/ 6862/4940 - acesso em: 1 dez. 2015.]

COLLING, L.; SANT'ANA, T. Um breve olhar sobre a transexualidade na mídia. In: Coelho, M. T. A. D.; SAMPAIO, L. L. P. (org.). Transexualidades: um olhar multidisciplinar. Salvador, EDUFBA, 2014, pp.255-266.

Della Porta, D. In-Depth Interviews. In: Della Porta, D. (org.). Methodological practices in social movement research. Oxford, Oxford University Press, 2014a, pp.397-417.

Della PorTA, D. Social Movements Studies and Methodological Pluralism: An Introduction. In: DELLA PORTA, D. (org.). Methodological practices in social movement research. Oxford, Oxford University Press, 2014b, pp.1-20.

FACCHINI, R. Movimento homossexual no Brasil: recompondo um histórico. Cadernos AEL, vol. 10, n 18/19, Campinas-SP, Arquivo Edgard Leuenroth/Unicamp, 2003, pp.81-125 [https://www.ifch.unicamp.br/ojs/index.php/ael/article/view/2510/1920 - acesso em: 1 nov. 2013.]

FouCAUlT, M. História da sexualidade I a vontade de saber. 19.ed. Rio de Janeiro, Graal, 2009.

FRY, P. Da hierarquia à igualdade: a construção histórica da homossexualidade no Brasil. In: FRY, P. Para inglês ver: identidade e política na cultura brasileira. Rio de Janeiro, Jorge Zahar Editores, 1982, pp.87-115. 
GoHn, M. da G. Teorias dos movimentos sociais: paradigmas clássicos e contemporâneos. 11.ed. São Paulo, Edições Loyola, 2014.

GREEN, J. N. Além do carnaval: a homossexualidade masculina no Brasil do século XX. São Paulo, Editora UNESP, 2000.

LEITE Jr., J. Nossos corpos também mudam: a invenção das categorias "travesti" e "transexual" no discurso científico. São Paulo, SP, Annablume, 2011.

MACHADO, F. V. Muito além do arco-íris. A constituição de identidades coletivas entre a sociedade civil e o Estado. Dissertação (Mestrado em Psicologia), Faculdade de Filosofia e Ciências Humanas, Universidade Federal de Minas Gerais, Belo Horizonte, 2007.

MELUCCI, A. Challenging codes: collective action in the information age. Cambridge; New York, Cambridge University Press, 1996.

NogueIRA, Sayonara; Aquino, Tathiane Araújo; CABRAL, Euclides Afonso. Dossiê: a geografia dos corpos das pessoas trans (2016). Uberlândia, Rede Trans Brasil, 2017.

PERES, W. S. Travestis brasileiras: dos estigmas à cidadania. Curitiba, Juruá Editora, 2015.

Rago, M. A aventura de contar-se: feminismos, escrita de si e invenções da subjetividade. Campinas, SP, Editora Unicamp, 2013.

ScotT, J. W. A invisibilidade da experiência. Projeto História, São Paulo, vol.

16 , 1998 [http://revistas.pucsp.br/index.php/revph/article/download/11183/819 4 - acesso em: 16 mar. 2016].

SimÕES, J. A.; FACCHINI, R. Na trilha do arco-íris: do movimento homossexual ao LGBT. São Paulo, Fundação Perseu Abramo, 2009.

TEIXEIRA, F. do B. Dispositivos de dor: saberes - poderes que (con)formam as transexualidades. São Paulo, Annablume; Fapesp, 2013.

Tilly, C.; WoOD, L. J. Social movements, 1768-2012. 3.ed. Boulder, CO, Paradigm Publishers, 2013.

WEISS, R. S. Learning from strangers: the art and method of qualitative interview studies. New York, Free Press, 1995. 


\section{Entrevistas}

Benzaquen, Carl. Entrevista concedida a Thiago Coacci. Contagem, 02 de dezembro de 2015.

La Roche, Walkíria. Entrevista concedida a Thiago Coacci. Belo Horizonte, 04 de fevereiro de 2016.

Lima, Anyky. Entrevista concedida a Thiago Coacci. Belo Horizonte, 02 de dezembro de 2015.

Lima, Gisella; Souza, Bruno. Entrevista concedida a Thiago Coacci. Belo Horizonte, 09 de dezembro de 2015. 